\title{
SOCIAL CRITICISM OF ASIAN CULTURE IN FILM "TO ALL THE BOYS I'VE LOVED BEFORE” WITH BARTHES' POPULAR CULTURE THEORY
}

\author{
Oleh: \\ Kurnia Dwi Alfianto 1 ) \\ Altobeli Lobodally ${ }^{2)}$
}

\begin{abstract}
Mass media often perceived Asian Culture as a powerless culture. Just like in To All the Boys I've Loved Before film that criticizing Asian culture. This study aimed to unveil the social criticism of Asian culture depicted on To All the Boys I've Loved Before. This qualitative study using Popular Culture Theory with Roland Barthes' semiotic analysis method by three elements of analysis (denotation, connotation, and myth). This study unveiled that the social criticism of Asian culture is linked with its collectivistic culture and interdependent characteristic, also overly-controlled Asian parents. This study also found the shift and consolidation of myth of Asian culture. Other than that, social criticism of Asian culture depicted on the film is the form of low culture and used as the asset to gain profit. Therefore, Asian culture has been marginalized and wrapped as a form of commercialized culture.
\end{abstract}

Keywords: asian culture, popular culture, film, social criticism, semiotics

\begin{abstract}
ABSTRAK
Budaya Asia seringkali dipandang sebelah mata dan tidak lebih baik dari Budaya Barat. Seperti Film To All The Boys I've Loved Before yang mengkritisi Budaya Asia. Tujuan penelitian ini adalah untuk membongkar kritik sosial terhadap Budaya Asia yang ada pada Film To All The Boys I've Loved Before. Penelitian ini menggunakan Teori Budaya Populer dengan pendekatan kualitatif dan metode analisis semiotika Roland Barthes dengan tiga elemen analisis yaitu denotasi, konotasi, dan mitos. Penelitian ini mengungkap bahwa kritik sosial terhadap Budaya Asia sarat dengan karakteristik collectivistic culture, interdependent, serta orang tua dari Budaya Asia yang terlalu mengatur. Melalui penelitian ini, peneliti juga menemukan adanya pergeseran dan pemantapan mitos Budaya Asia. Selain itu, kritik sosial terhadap Budaya Asia di dalam film tersebut merupakan bentuk low culture yang dijadikan sebagai alat untuk meraup keuntungan. Sehingga melalui film ini Budaya Asia mengalami marginalisasi yang dikemas sebagai sebuah bentuk komersialisasi.
\end{abstract}

Kata kunci: budaya asia, budaya populer, film, kritik sosial, semiotika

\footnotetext{
${ }^{1}$ Ilmu Komunikasi, Fakultas Industri Kreatif, Institut Teknologi dan Bisnis Kalbis Jalan Pulomas Selatan Kav.22, Jakarta 132101. Email: kurniadwialfianto@gmail.com

${ }^{2)}$ Ilmu Komunikasi, Fakultas Industri Kreatif, Institut Teknologi dan Bisnis Kalbis Jalan Pulomas Selatan Kav.22, Jakarta 132101. Email: altobeli.lobodally@kalbis.ac.id
} 


\section{PRELIMINARY}

Asian culture is often underestimated, where Asian culture is considered no better than Western culture. This view can easily be found in the context of mass communication. One of the mass communication products that are often used in expressing social criticism of Asian culture is film. Through films, Asian culture is not only reflected negatively, but has now become a product of popular culture.

Culture, which is a product of creativity, taste, and human work, has now become an industrial product as well as a form of commercialization for the world of mass communication. Soemardjan and Soemardi stated that culture is all the creations, tastes, and works of society. In this case, creativity is the ability of people to think about living in society and matters related to science. Rasa is how the human soul manifests its expression into elements such as religion, art, and ideology. Work is technology, material, or material that humans need to live and process the surrounding resources (Soekanto, 2015: 151).

So that culture takes on the task of shaping society into a much better pattern of life. However, not for the film industry. Movies actually have values to make a profit. Like a film that packs Asian culture as a mass communication product. In this research, the film in question is Film To All The Boys I've Loved Before. The film tells about the romance drama of a young AsianAmerican girl who secretly writes love letters to five boys she likes. Then the drama begins when the five letters are scattered among the recipients.

One of the pieces of the scene that shows the social depiction and criticism of Asian culture in the film is the scene of a teenage girl of AsianAmerican descent, Lara Jean (played by Lana Condor) who writes love letters to five men she has ever loved in silence. -the silence is Kenny, Peter, Lucas, John, and Josh. The five love letters were not made to be given to the recipient, but only as a form of secret expression of Lara Jean's love for the five men who were then stored in an used box where the hat was given by her mother.
Basically, these scene pieces are seen only as a preliminary depiction of the journey of Lara Jean's love story. However, the scene turned out to be a form of social criticism of the people of Asian culture which was depicted in the character of Lara Jean. People from Asian cultures are considered to be shy and do not express feelings directly.

This is related to high-context cultures which are characteristic of Asian Culture. According to Samovar et.al., "people from highcontext cultures tend to be aware of their surroundings and can express and interpret feelings without verbally stating them." That way, people with high-context cultures tend not to express their feelings directly (Samovar, et.al., 2010: 216).

In addition, it is also related to the differences between Asian and Western cultures in upholding frankness or candor in communication. De Mente (in Samovar et.al., 2010: 186) says that Western culture (like Americans and most Europeans) prioritizes directness, detail, and direct debate based on facts and assumptions. Meanwhile, in contrast, Asian culture (one of which is reflected in the Japanese), is accustomed to expressing their original thoughts or frankness only in a personal environment (Samovar et.al., 2010: 186).

According to Hofstede's research on the value of individualism / collectivism in fifty countries, the United States is the country with the highest individualism value. Meanwhile, other Asian countries such as Japan, the Philippines, Malaysia, Hong Kong, and South Korea are far from America's ranking. This indicates how Asian culture is identified with its collectivism value (Samovar, et.al., 2010: 199).

Asian culture also appears in mass communication products, such as films. Ida said that "In a world that is already filled with images or pictures and writings in newspapers, television, films, videos, radio, advertisements, novels and so on, the way we define ourselves or define our identity and the environment. our surroundings are varied and different from one another. In the era - what he calls the "media saturated world" - 
when human life has been mediated by mass media, and the way we see, perceive, understand, and behave towards social reality has been overshadowed by mass media. What is around us determines how we act and behave towards it, because what we see, watch, read, listen to, and enjoy from the mass media seems to "teach" us to do what we want. In fact, our culture is actually also shaped by the mass media which we enjoy every day"(Ida, 2014: 3).

The mass media is a medium for reinforcing popular culture. In general, what is meant by popular culture is how something is made or described as something that has interests and is liked by many people even though it is actually different from the reality (Strinati, 2007: 2-3). This study seeks to find the interests behind the mass communication product, namely Film To All The Boys I've Loved Before.

Film is a text. Textual analysis views culture as "a collection of social practices in which meanings are produced, circulated and exchanged in society" (Ida, 2014: 60).

Text analysis that will be used in this research is Semiotic Text Analysis. According to Kriyantono, Semiotic Analysis aims to find the meaning of a sign which also includes the things hidden behind a sign (Kriyantono, 2016: 266). The semiotic analysis used in this study is the Barthes Semiotic Analysis. Barthes's view reveals that every code or sign that exists is not just present. However, each existing code or sign is certainly historically and socially specific in accordance with the particular interests and goals behind the presence of these codes and signs (Strinati, 2007: 124).

This study aims to uncover social criticism of Asian culture in the film To All The Boys I've Loved Before on Netflix. So that through this research, social criticism of Asian culture will be parsed in the form of both audio and visual signs. So this research focuses on observing how the signs, symbols, and symbols in the film To All The Boys I've Loved Before. Especially regarding Asian culture which is depicted through the main character of the film, namely Lara Jean.

\section{RESEARCH METHODS}

The paradigm used in this research is the critical paradigm. Ronda (2018: 14) calls the critical paradigm a knowledge paradigm "which" always suspects "there is an interest behind something." The critical paradigm does not only criticize injustice in a dominant system (or also called capitalism), but also tries to change the structure and system to be fairer (Ronda, 2018: 14). Just like constructivism, critical paradigm is classified as subjective research (Ronda, 2018: $15)$.

The critical paradigm is born from critical theory that cannot be separated from the legacy of Marxism in the entire philosophical framework of knowledge (Ronda, 2018: 15). Miller (in Ronda, 2018: 15) said that theorists in the critical tradition expect scientists to be responsible by not simplifying the picture of the social world, but can become active agents in reshaping and creating fundamental changes in people's lives.

Then, this study uses a qualitative approach. According to Kriyantono, qualitative data is data in the form of words, sentences or narratives (Kriyantono, 2016: 37). Qualitative research is carried out with the aim of explaining a phenomenon as deeply as possible through indepth data collection. In qualitative research, the emphasis is on the depth or quality of the data, not the amount or quantity of data (Kriyantono, 2016: 56-57). Meanwhile, according to Fiske (in Vera, 2014: 2) semiotics is "the study of signs and the meaning of the sign system; the science of signs, about how meaning is constructed in the "text" media. "

With a qualitative approach, this study uses content analysis semiotics as the research method. Charles Sanders Pierce describes semiotics as the study of signs and everything related to them. Everything related to the sign in question is the way it functions, its relationship with other signs, their delivery and reception by those who use it (Vera, 2014: 2). In addition, according to Eco (in Sobur, 2009: 95) terminologically, a sign is a science that studies a wide range of objects, events, and entire cultures as signs. Then Barker 
explained that semiotics "explores how the meaning constructed by the text has been obtained through the arrangement of signs in a certain way and through the use of cultural codes" (Vera, 2014: 2).

This study will attempt to reveal the social criticism of Asian culture that appears in the film To All The Boys I've Loved Before through a qualitative approach. The analytical method used is the semiotic content analysis method.

Furthermore, this research uses descriptive research. This type of research is used to describe the reality that occurs, but without explaining the relationship between variables (Kriyantono, 2016: 69). Descriptive research is in the form of words, pictures, and not numbers or statistics. These words or images can be sourced from certain photos, videos, notes or text, as well as other official documents (Vardiansyah, 2008: 70).

Thus, this type of research seeks to unravel holistically or as a whole about how social criticism of Asian culture is present in the film To All The Boys I've Loved Before. After that, the results of this study will be described descriptively or in words.

Data collection techniques used by researchers are primary and secondary. Primary data were obtained from observations in the film To All The Boys I've Loved Before. As well as secondary data is literature (books, journals and articles) that are relevant and support the data that researchers get.

The data analysis technique used was Roland Barthes' semiotic analysis. In analyzing the meaning of signs, Roland Barthes applies a two-stage or two-order of signification model of significance.

In Roland Barthes' semiotic analysis model, the denotation or the most obvious meaning of the sign is the first stage of significance. In denotation, the signifier and signified are related in a sign to external reality (Sobur, 2009: 128). Furthermore, the connotation or interaction that occurs when the sign is interpreted by the emotions and cultural values of the message recipient is the second stage of significance. In the second stage of significance, the sign works by means of a myth. Myth is how culture explains or understands the reality or natural phenomena that exist (Sobur, 2009: 128).

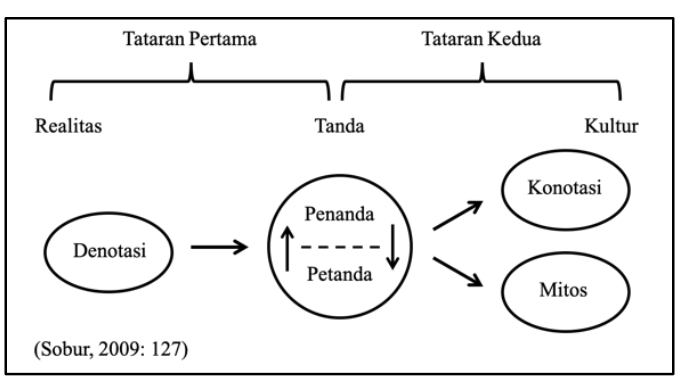

Figure 1 The two-stage significance of Roland Barthes (Sobur, 2009: 127)

\section{RESULTS AND DISCUSSION}

This study uses research materials from Film To All The Boys I've Loved Before. In one of the scenes shows the following image:

$$
\text { 4.30 AM }
$$

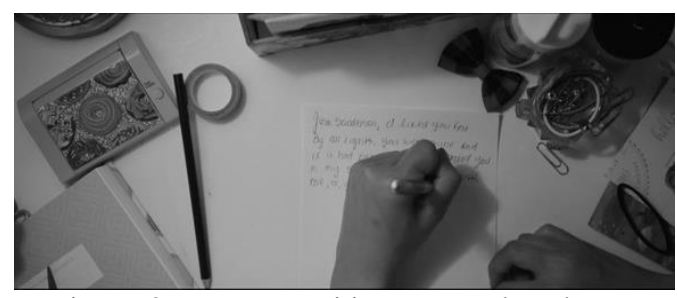

Picture 2 Lara Jean writing a secret love letter

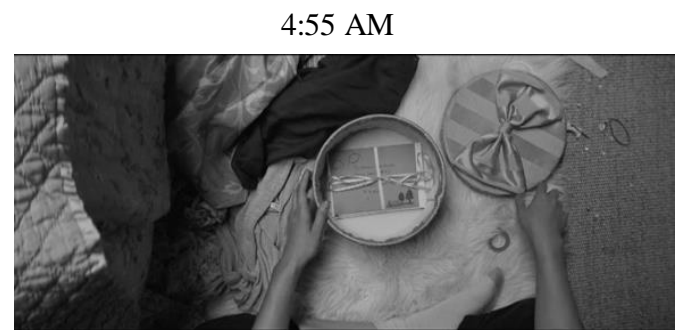

Picture 3 Lara Jean's secret box

\section{Denotation}

In Figure 2, you can see the female main character's left hand writing on a white sheet of paper. The letter that is being written is on a flat 
white sheet with some stationery items and a red ribbon around it.

Whereas in Figure 3 you can see the female main character's hand holding a blue circleshaped storage area containing several letters tied with pink ropes. Next to the storage area, you can see the cover of the circle colored storage area colored blue with stripes accented by a large matching ribbon on the lid. The storage area and lid are located on a pink fur base. Then around him there were some clothes lying just like that.

Then, when Figure 2 to Figure 3 takes place, there is the VO (Voice Over) voice of the main character of the film. In the VO, the female main character says:

"I write a letter when I have a crush.. so intense I don't know what else to do. Rereading my letters reminds me of how powerful my emotions can be, how allconsuming.

And Margot would say I'm being dramatic, but I think drama can be fun..."

Figures 2 and 3 use angle with the high angle type. The shooting technique used is close-ups.

\section{Connotation}

Berger states that the close-up shooting technique means intimacy or intimacy (Berger, 2012: 41). In this way, Figure 2 and Figure 3 illustrate the "intimacy" of Lara Jean's feelings for the man she secretly likes. In Figure 2 the intimacy of Lara Jean's feelings is shown through the secret love letter she wrote to Josh. Whereas in Figure 3 the intimacy of Lara Jean's feelings is depicted through secret love letters that she has written and stored in the circular storage box. In other words, in Figure 3 invites us to dig into Lara Jean's heart, which is described as a circular storage box with her feelings of love which are described as secret love letters that she made and kept in the storage box.

Furthermore, in Figure 2, the paper the female lead uses to express her feelings is white. seen from the color of the table as a base for writing. According to Nugroho, the color white has a positive meaning in the form of purity, innocence, hope and simplicity. In addition, the dominance of white is also on the other hand, the color white also has a negative meaning in the form of being empty and giving up (Nugroho, 2008: 38). In this way, the sheet of white paper used to write the secret love letter illustrates the purity and hope of Lara Jean's feelings for Josh which can only be expressed simply on a piece of white paper. In addition, the white paper and the dominance of white around it also illustrates the emptiness and surrender of Lara Jean in conveying and fighting for her secret love. Then, on the side of the paper that is being written, there is a red ribbon. In "Introduction to Color Theory", Nugroho stated that in Asian culture, red is usually interpreted as luck (Nugroho, 2008: 38). In this way, the little red ribbon depicts little Lara Jean's luck, especially in matters of love, where she prefers to harbor her feelings and pour them through secret love letters rather than fighting and conveying her feelings directly.

Then, in Figure 3 you can see a circular storage area along with a blue lid. According to Nugroho, blue has a positive meaning in the form of security, trust, truth, and love. However, blue also has a negative meaning in the form of sadness and depression (Nugroho, 2008: 37). In this way, the storage place that her mother gave her represents a place that Lara Jean believes in and feels safe to accommodate all the truth about the love she feels. However, on the other hand, the storage place that her mother gave her also depicts Lara Jean's sadness and depression, who cannot express her feelings directly, so that she can only pour 
it through secret love letters that she keeps in that storage.

Meanwhile, according to Samovar et.al., people from Asian cultures (one of which is reflected in the Japanese), are accustomed to expressing their original thoughts or frankness only in a personal environment (Samovar et.al., 2010: 186). Not only that, in Asian culture (one of which is reflected in the Chinese) tends not to express and show their feelings - especially emotional feelings — straightforwardly (Samovar et.al., 2010: 189). Based on that, Figure 2 illustrates how Lara Jean as a descendant of Asian culture prefers to be candid and show her emotional feelings directly to the man she likes. Lara Jean then expressed her feelings by writing a secret love letter which became her personal sphere.

Then, in the book "Introduction to Semiotics: Signs in Contemporary Culture", Berger states that Barthes revealed that in Asian culture, especially Japan, the use of boxes to store something is more meaningful than the contents in it (Berger, 2015: 32). More clearly, in his book entitled Empire of Signs, Barthes explains the following: "It is as if, then, the box were the object of the gift, not what it contains ... it is worth what it conceals, protects, and yet designates: it puts off ... as if the package's function were not to protect in space, but to postpone in time...".

(Barthes, 1992: 46). In other words, actually boxes in Asian culture are more meaningful and meaningful than what is stored in them. In Figure 3, you can see a circular storage box or place that was a gift from her deceased mother, used by Lara Jean to keep her five secret love letters. In this way, Figure 3 illustrates how valuable a storage box is, because it symbolizes the figure of his mother who, although dead, will still be the right place to pour out all of Lara Jean's heart.

So based on this explanation, this scene shows a social criticism of Asian culture, namely people with Asian culture do not dare to express their thoughts and heart's contents especially their emotional feelings - to others. In addition, Asian culture is considered incapable of being straightforward and only able to express what is actually felt only in the personal sphere. Another social criticism conveyed is that people with Asian culture can only believe in one figure as a place for all true feelings to flow, where in this film a box depicts a box where Lara Jean keeps her secret letter as a representative of her dead mother. In other words, the scene criticizes how people with Asian culture do not dare to express everything honestly and directly, but instead "hoard" things that they cannot express only to themselves or even "spill" it to others who considered to believe.

In Roland Barthes' semiotics, to the second stage of significance, signs also relate to myths or myths. Myth is how culture understands various aspects related to the existing reality (Sobur, 2009: 128). Based on the analysis of the denotation and connotation of Roland Barthes which was applied to the film To All The Boys I've Loved Before regarding social criticism of Asian culture, the researcher found that:

1) Asian culture does not appreciate all forms of expression of emotion if it can damage the harmony of the existing situation. 1. Even people with Asian Cultures are described as "covering" their true individual feelings and desires in a seemingly fine manner in order to avoid any potential problems arising from the consequences.

2) People with Asian Cultures do not dare to express their thoughts and feelings especially their emotional feelings — to others. So that people from Asian cultures are not able to be candid and are only able to express what they really feel only in the personal sphere. 1. As such, people from Asian Culture are considered not to dare to reveal things honestly and directly, but "hoard" things that they cannot reveal only to themselves or even "spill" to others they trust. 
3) Parents with Asian cultures are too controlling in the family, even ignoring the consequences for sacrificing the happiness of their children's lives.

4) People with Asian Culture are very dependent on others in everyday life and cannot be individually independent

5) People with Asian Culture place too much importance on harmony and stability of relationships with those closest to them. 1 . Thus sacrificing true feelings and thoughts not to be expressed.

6) People with Asian Cultures do not dare to face conflict head-on and tend to avoid or need help from others.

7) People with Asian Culture are not able to solve problems directly and responsibly. 1. People with Asian Culture solve problems by compromising through agreements that seem to benefit both parties.

8) People with Asian Culture take gestures of intimacy too seriously. 1. So that it can misinterpret gestures made by people from other cultures.

The myth that researchers found about Asian culture as a social criticism that is "trapped" in the film To All The Boys I've Loved Before is a western mass media depiction of Asian culture. Meanwhile, Barthes states that myth is a communication system which is a message, a way of signifying, a form, and one type of speech that is carried out through discourse (Strinati, 2016: 137). Myths have also been believed and held in a social class in society. So that other cultures also have their own representations or depictions of Asian Culture.

According to Kim in the Journal of Multicultural Education Review, United States Culture has the view that Asian culture, one of which is like the Japanese, is people who are "greedy, ambitious, and covertly scheming to control the U.S." or greedy, ambitious, and cunning. Then Kim also quoted Shim as saying that the existence of Asian women in US popular theater and film is seen only to "fulfill White's desires; when their lovers leave they disappear "or the fulfillment of the desires of American men, so that if the idol of the Asian people leaves them, they will be helpless. Furthermore, according to Kim, in Hollywood stereotypes, Asians are generally described as experiencing a "tragic forbidden lover," where Asians fall in love with Americans until they sacrifice themselves (Asians - pen.) Just to pay back the love of Americans. The US mainstream media also constructs that people with Asian cultures are more interested in science than humans themselves, so it is called "smart and diligent but robotic" (Kim, Multicultural Education Review, 5: 2, 2013, pp. 23-28).

This is also in line with Hyun Park's statement that Asian women are seen as "sexually excessive and deviant" or sexually deviant and strong desires. In fact, according to Hyun Park, there is an assumption that "proper Korean / Asian women live only to please such men." Then Asians are also considered "technical robots" who cannot break the glass ceiling because they lack creativity and passion, "which is related to differences in individualism and collectivism between American culture and Asian culture (Hyun, 2014).

Meanwhile, in his paper presented at the Asia-Pacific Studies Workshop in Australia and Europe: A Research Agenda for The Future, Lawson (2002) said that European culture argues that just like Western culture, they are also part of the "individualistic West". So that Asian culture is part of the "communitarian East" and is different from European culture.

Furthermore, Paterson and Nothias said, in African culture, there are two views about Asian people, one of which is like the Chinese. First, Asians are seen as "humble, quiet and successful, an image grounded in white paternalism." In other words, Asians are viewed as humble, reserved, and successful. But on the other hand, African culture also has a view that associates Asians with "cunningness, secrecy, deceit, thief, and cruelty" or cunning, full of secrets, con artists, thieves and cruelty (Paterson \& Nothias, Journal of Communication, Culture \& Critique, 9, 2016, pp. 112-117). 
Meanwhile, according to Olivia Khoo, in Australia, people with Asian cultures, especially women, are considered "self-sacrificing creatures" or creatures who are willing to sacrifice themselves. Furthermore, Asian people in Australian Culture are also depicted as unfortunate people when their love stories with people from different cultures do not end happily (Khoo, 2006 : 52-54).

Each culture has its own views on Asian Culture. Thus, in this study, researchers found a shift and consolidation of myths about Asian culture. The shift that occurs is when the Asian culture in the film depicts the parents of Asian culture full of rules and how people with Asian cultures tend to avoid conflict, in contrast to other cultural views of Asian culture. So that it can be described in Table 1.

Table 1 Shifting myths of Asian Culture Myths in Society

- Greedy, ambitious, and covertly scheming to control the U.S.

- Fulfill White men's desires

- Tragic forbidden lover

- Smart and diligent but robotic

- Communitarian East

- Humble, quiet, successful

- Cunning, full of secrets, trickster, thief and cruel

- Self-sacrificing creatures

\begin{tabular}{|ll|}
\hline \multicolumn{1}{|c|}{ Myths in movies } \\
\hline - & Parents are full of rules \\
- & Avoid conflict \\
\hline
\end{tabular}

Meanwhile, the stabilization that occurs is when in the film To All The Boys I've Loved Before, people from Asian cultures tend to cover their expressions of emotion. This is related to the view of African Culture which considers people from Asian Culture to be full of secrets. The next stabilization was when in the film To All The Boys I've Loved Before, it depicted that people from Asian cultures were not independent. This is related to the view of European Culture which views people from Asian Culture as "East communitarian." Then, stabilization also occurs when Asian culture is depicted as concerned about harmony and stability in the relationship in the film. This is related to the view of European Culture which considers Asian Culture as "East communitarian." Then, stabilization also occurs when in the film Asian Culture tends to sacrifice their own feelings. This is related to the view of Australian culture towards Asian culture, namely as "self-sacrificing creatures" or creatures that are willing to sacrifice themselves. Not only that, this stabilization also occurred when Asian Culture was depicted as solving problems by compromising through agreements that seemed to benefit both parties. This is related to the view of European Culture which views people from Asian Culture as "East communitarian." Not only that, consolidation also occurs when Asian culture is depicted as taking gestures of intimacy too seriously, so that they can misinterpret gestures made by people from other cultures. This is also related to the view of European Culture which views people from Asian Culture as "East communitarian." So that it can be described in Table 2.

Table 2 Establishment of Asian cultural myths Myths in Society

- Greedy, ambitious, and covertly scheming to control the U.S.

- Fulfill White men's desires

- Tragic forbidden lover

- Smart and diligent but robotic

- Communitarian East

- Humble, quiet, successful

- Cunning, secretive, con, thief and cruel

- Self-sacrificing creatures

\begin{tabular}{|l|}
\hline \multicolumn{1}{|c|}{ Myths in movies } \\
\hline - Cover expression of emotion \\
- Not independent \\
- Concerned with the harmony and stability \\
of the relationship \\
- Give up feelings \\
\hline
\end{tabular}


- Solve problems with "win-win solutions"

- Take the gesture of intimacy seriously

This study finds social criticism of Asian culture which is "trapped" in the film To All The Boys I've Loved Before. Through this research, the researcher found a shift and consolidation of myths about Asian culture.

In the film, researchers found that Asian culture is depicted through the main character of the film, namely Lara Jean, who is a teenage woman of Asian descent. Through the character Lara Jean, people from Asian Culture are described as people who "cover up" their true feelings by acting as if they are okay, do not dare to express feelings, are not independent, place too much importance on harmony and stability of relationships with their surroundings, even sacrificing their feelings alone in order to maintain harmony and relationships with the surrounding. Not only that, through the character of Lara Jean, people from Asian Culture are also portrayed as people who solve problems by compromising through agreements that seem to benefit both parties, and take gestures of intimacy from others too seriously. In addition, social criticism of Asian culture is also conveyed through the depiction of a mother who is too controlling to ignore the happiness of their children.

The myth embedded in the film is a form of social criticism of Asian culture. Social criticism that comes through myths in films is social criticism that is conveyed indirectly. So that the film To All The Boys I've Loved Before is a medium for conveying social criticism by western culture against Asian culture with all its collectivistic culture characteristics.

Social criticism of Asian culture is conveyed indirectly through the use of various signs, symbols and symbols that describe the characteristics of Asian culture. The depiction of the characteristics of Asian culture is present through the main character Lara Jean who is of Asian descent. Through the depiction of the character Lara Jean in the film, western culture indirectly conveyed its social criticism of Asian culture which is considered collectivistic, interdependent, and other collectivistic East characteristics.

This study uses Popular Culture Theory. In Popular Culture there are three main arguments. The three arguments are what or who determines popular culture, how industrialization and commercialization affect popular culture, and the ideological role of popular culture.

In this film, Awesomeness Films and Overbrook Entertainment as the makers of the film To All The Boys I've Loved Before are the parties that produce social criticism of Asian culture as popular culture. However, the two parties cannot be separated from the influence of the industrial order and commercialization.

As an industry, the two market players cannot separate themselves from industrialization and commercialization efforts. So that the attempt to describe social criticism of Asian culture is nothing more than an attempt to reap profits. This means, as market players, Awesomeness Films and Overbrook Entertainment do not see the excesses arising from social criticism efforts against Asian Culture, that hatred will arise against people from Asian Culture.

Social criticism of Asian culture has even become an ideology in the film To All The Boys I've Loved Before. This ideology is conveyed through every scene, especially through the main character Lara Jean who is described as a person of Asian descent.

Film as a product of mass communication cannot be separated from its efforts to "insert" ideology. The ideology conveyed in this film is that people from Asian cultures are full of their collectivistic culture. This is conveyed through the effort to portray Lara Jean as a person of Asian descent who is very dependent on others and covers her feelings for the harmony of the surrounding relationship.

The ideology of Asian culture that is "tucked" in the film is a form of low culture. Low culture or low culture related to mass culture is present as a result of industrialization and commercialization which changes the existing 
cultural situation of the people. Mass culture is also a culture that presents a substitute or false morality. Mass culture is able to denigrate all cultures, then recreate them with their own image.

Meanwhile, films as cultural products should function to provide information, entertain, and educate. This study attempts to enlighten that Asian culture is not only as criticized in the film To All The Boys I've Loved Before. Social criticism that is present in the mass media, such as in the film To All The Boys I've Loved Before, is an attempt to dominate Western culture which considers other cultures - in this case especially Asian cultures - no better than their own. In fact, it is undeniable that Asian cultural values can be "trapped" in the text to become low-value which is merely entertainment. So that Western culture, through cultural products such as films, embeds Asian culture only for the sake of profit.

In addition, Awesomeness Films and Overbrook Entertainment as filmmakers should realize that Asian culture is not a low value thing that can be used as an element of attractive entertainment that brings profit, but an element of life in Asian society that needs to be respected. This should be respected and guarded because the "trapping" of Asian culture in a mass communication product in the form of a film can easily change and "shape" the views of other cultures on Asian culture. That way, the embedding of Asian culture in the film To All The Boys I've Loved Before has the potential to change and "shape" the global audience's view of Asian culture so that they slowly assume that what is "presented" in the film is a real depiction of Asian culture.

Then, the embedding of Asian culture in cultural products such as films has long "misled" the world's view of Asian culture. This happens through the continuous efforts of cultural hegemony in films. So that Asian culture is no longer seen as something valuable and worthy of respect. Through the "fake" depiction of films, Western Culture of Asian Culture causes people of other cultures to also view Asian Culture as how Western Culture "presents" Asian Culture. Through this research, the researcher hopes that the world view of Asian culture should be "corrected" by criticizing the mass media especially films - which wrongly pinpoint Asian culture as a potential profit, thus degrading Asian culture itself.

\section{CONCLUSION}

Through the results of interpretations and analysis of denotations, connotations and myths in the film To All The Boys I've Loved Before, researchers get some social criticism of Asian culture that is present in the film.

The first criticism, social criticism of Asian culture is depicted through the main character of the film, Lara Jean, who is said to be of Asian descent. Lara Jean's character herself is described as a person who does not dare to openly express her heart because she is more concerned with harmonious relationships between herself and her surroundings. So, through Lara Jean, people from Asian Culture are criticized as people who "hide" their feelings, even though their hearts actually want things that are contrasted with the behavior shown.

Social criticism of Asian culture also appears through the depiction of Lara Jean's character who always depends on her friend, Christine. Through this description, Asian culture is criticized for the value of collectivistic culture which generally characterizes Asian culture. So that people from Asian cultures are considered not independent, or in other words, always dependent on other people.

In addition, social criticism of Asian culture also appears through the character of the mother. Even though it was told that he had died, his mother actually advised that Margot should not date in college. Then Margot obeyed her mother's message even though she sacrificed her happiness. Thus, Asian Culture has been criticized that parents from Asian Culture overly organize their families and children, even to the 
point of sacrificing the happiness of their own children.

Not only that, based on the analysis carried out in the film To All The Boys I've Loved Before, researchers found a shift and strengthening of myths between the myths contained in the film and the myths that have settled in society. The shift that occurs is when the Asian culture in the film depicts the parents of Asian culture full of rules, in contrast to other cultural views of Asian culture. Meanwhile, the stabilization that occurs is when the Asian culture in the film is depicted as tending to cover their expression of emotion, which is related to the African cultural view which considers people from Asian culture to be full of secrets. The next stabilization is when people from Asian Culture in the film are depicted as not independent, related to the European Cultural view which sees people from Asian Culture as "East communitarian." Then, the stabilization also occurred when Asian culture depicted in the film emphasized harmony and stability of relations, related to the view of European Culture which considers Asian Culture as "East communitarian." Then, stabilization also occurs when in the film Asian cultures are depicted as being willing to sacrifice their own feelings, in relation to the Australian culture's view of Asian culture, namely as "self-sacrificing creatures" or creatures that are willing to sacrifice themselves.

Social criticism of Asian culture which is depicted in various scenes in the film To All The Boys Ive Loved Before has become the "tucked" ideology in the film. The ideology conveyed is how people from Asian culture are full of their collectivistic culture.

Then the ideology of "tucked" Asian culture is a form of low culture or low culture that presents a false morality of Asian culture. This is due to industrialization and commercialization so that it is only oriented towards profit.

Based on this, this study attempts to enlighten that Asian culture is not only as criticized in the film To All The Boys I've Loved
Before. Then, Awesomeness Films and Overbrook Entertainment as filmmakers should have realized that the ideology they "inserted" resulted in the formation of a negative world view of the collectivistic culture characteristics of Asian culture. In addition, we need to "improve" how Asian culture is seen in the eyes of other cultures by criticizing films that embed Asian culture only to make a profit.

\section{REFERENCES}

\section{Books}

Barthes, R. 1992. Empire of Signs. Amerika Serikat: Noonday Press.

Berger, A. A. 2012. Media and Society: A Critical Perspective, 3rd Edition. Plymouth: Rowman \& Littlefield.

Berger, A. A. 2015. Pengantar Semiotika: Tandatanda dalam Kehidupan Kontemporer. Yogyakarta: Tiara Wacana.

Ida, R. 2014. Metode Penelitian Studi Media dan Kajian Budaya. Jakarta: Kencana.

Hyun Park, J. C. 2018. "The failure of Asian American representation in All-American Girl and The Cho Show." Gender, Place \& Culture, 21:5 (2014), pp. 637-649.

Khoo, O. 2006. "Telling Stories: The Sacrificial Asian in Australian Cinema." Journal of Intercultural Studies, 27:1-2, (2006), 4563.

Kim, Y. 2013. "Representation of People of Asian Descent in Mainstream Mass Media within the United States." Multicultural Education Review, 5:2. hal. 20-48.

Kriyantono, R. 2016. Teknis Praktis Riset Komunikasi: Disertai Contoh Praktis Riset Media Public Relations, Advertising, Komunikasi Organisasi, Komunikasi Pemasaran. Jakarta: Kencana. 
Lawson, S. 2002. "Europe and The Asia-Pacific: Culture, Identity and Representations of Region." Makalah disampaikan dalam Workshop Asia-Pacific Studies in Australia and Europe: A Research Agenda for the Future, Australian National University.

Nugroho, E. 2008. Pengenalan Teori Warna. Yogyakarta: Andi.

Paterson, C. \& Nothias, T. 2016. "Representation of China and the United States in Africa in Online Global News." Jurnal Communication, Culture \& Critique, 9, hal. 107-125).

Ronda, A. M. 2018. Tafsir Kontemporer Ilmu Komunikasi. Tangerang: Indigo Media.

Samovar, L. A., et.al. 2010. Communication Between Cultures, 7th Edition, International Edition. Wadsworth: Cengage Learning.

Sobur, A. 2009. Analisis Teks Media, Suatu Pengantar untuk Analisis Wacana, Analisis Semiotik, dan Analisis Framing. Bandung: Remaja Rosdakarya.

Sobur, A. 2013. Semiotika Komunikasi. Bandung: Remaja Rosdakarya.

Soekanto, S. 2015. Sosiologi Suatu Pengantar. Jakarta: Rajawali Pers.

Strinati, D. 2007. Popular Culture Pengantar Menuju Budaya Populer. Yogyakarta: Jejak.

Vardiansyah, D. 2008. Filsafat Ilmu Komunikasi. Jakarta: Indeks.

Vera, Nawiroh. 2014. Semiotika dalam Riset Komunikasi. Bogor: Ghalia.

Studiobinder. 2019. The Wide Shot: Creative Examples of Camera Movement and Angle. Retreived https://www.studiobinder.com/blog/wideshot-camera-angles-movements-examples/ 